Vol. 2 No. 1 Juni 2020

\title{
THE EFFECTIVENESS OF MNEMONIC TO TEACH VOCABULARY VIEWED FROM STUDENTS' CREATIVITY
}

\author{
Penulis 1 \\ Dhian Marita Sari \\ Sekolab Tinggi Ilmu Tarbiyah \\ Madani Yogyakartal \\ Yogyakarta \\ dbianmarita@gmail.com

\section{Penulis 2 \\ Zailani \\ Sekolah Tinggi Ilmu Tarbiyah \\ Madani Yogyakartal \\ Yogyakarta \\ zailaniye@gmail.com}

\section{Penulis 3}

\section{Retty Aureli}

Sekolah Tinggi Ilmu Tarbiyah

Madani Yogyakartal

Yogyakarta

rettyaurell@gmail.com

\begin{abstract}
To be able to enhance and support of English skills, learners previously have to master vocabulary. In contrast, students consider and see English as a foreign language that is not understood, unused, and feared. Beside, they easily forget the newly learned words that have been taught. Those are mostly problem that are faced of students in learning vocabulary. The objectives of this research are finding out whether: (1) mnemonic is more effective than direct instruction to teach vocabulary; (2) the students having high creativity have better vocabulary mastery than those having low creativity; (3) there is an interaction between teaching techniques and creativity in teaching vocabulary. This research was an experimental study.

Keywords . Mnemonic, Direct Instruction, Creativity.

Abstrak. Untuk dapat meningkatkan dan mendukung kemampuan bahasa Inggris, peserta didik sebelumnya harus menguasai kosakata. Sebaliknya, siswa menganggap dan melihat bahasa Inggris sebagai bahasa asing yang tidak dipahami, tidak digunakan, dan ditakuti. Selain itu, mereka mudah melupakan kata-kata yang baru dipelajari yang telah diajarkan. Itulah sebagian besar masalah yang dihadapi siswa dalam mempelajari kosakata. Tujuan dari penelitian ini adalah untuk mengetahui apakah: (1) mnemonic lebih efektif daripada instruksi langsung untuk mengajarkan kosakata; (2) siswa yang memiliki kreativitas tinggi memiliki penguasaan kosakata yang lebih baik daripada siswa yang memiliki kreativitas rendah; (3) terdapat interaksi antara teknik mengajar dan kreativitas dalam mengajar kosakata. Penelitian ini merupakan penelitian eksperimental.
\end{abstract}

Kata Kunci. Mnemonik, Instruksi Langsung, Kreativitas. 


\section{A. PENDAHULUAN.}

\section{Isi Pendahuluan}

Vocabulary is central and very important in language learning. It means that by mastering vocabulary, the learners will be able encourage the language either in spoken or written. They can also communicate with other people fluently and express their opinion or ideas conveniently. It is almost impossible to understand a written text without understanding vocabulary, oral is weakness, speaking practice is inconvenient to done, and learners are difficult to speak a fluent sentences because of lack of useful vocabularies. Not being able to understand the vocabulary that is needed in listening text is one of the most frustrating experiences for language learners 1. Cameron 2states that building a useful vocabulary is central to learning of a foreign language Thus, it can be recognized that vocabulary influences of someone's ability in learning english, including listening, writing, reading, and speaking. Nation states that there are four aspects that are needed to be taught by the teacher to teach vocabulary: (1) meaning; (2) spelling; (3) pronounciation; and (4) use.

On the other hand, teaching vocabulary for young learners can not be just by writing letters and words on the board in order to make the students are able to read and know the words. They have to learn a lot of words previously as a requairement to master the words. Beside, the students consider and see English as a foreign language that is not understood, unused, and feared. That's way they find difficult and seem not interest in learning process. Another problem that students mostly face in learning vocabulary is that they easily forget the newly learned words. Thus, students have to learn the way to keep remaining the words to learn vocabulary.

In real condition, many teachers still use direct instruction to teach vocabulary. In this technique, the teacher becomes the decision maker. The teacher control occurs when the teacher selects and directs the learning tasks. Joyce and Weil add that direct instruction provides feedback and correction for the students' mistake. The students' activity can be mainly passive and students just wait for the teacher's explanation of the word during the lessson. There are some steps applied in direct instruction: (1) Teacher goes over objective for the lesson; (2) Teacher demonstrates the skill correctly or presents step-by-step information; (3) Teacher checks the students'performing and provides feedback; and (4) Teacher sets conditions for extended practice and real life situations3.

To teach vocabulary, the teachers have to select the suitable technique that is supposed to maintain and motivate the students in joining the class. According to Cameron states that vocabulary memorizing activities can make central use of the idea of networks of meaning. Based on that theory, one of the techniques to teach vocabulary is by memorizing because vocabulary is generally a matter of remembering. Thornbury proves that to be able to teach vocabulary, it is important to know how words are remembered and stored in students' minds and how long term memory is

\footnotetext{
1 Arends, Richard I. 1997. Classroom Instruction and Management: United stated. McGraw-Hill. Page 75

${ }^{2}$ Celce-Murcia, M. (2001). Teaching English as a Second or Foreign Language. USA: Heinle and Heinle page 21

${ }^{3}$ Nunan, David. 1989. Designing Tasks for Communicative Classroom. Cambridge:

Cambridge University Press page 55
} 


\section{At-Turats: Jurnal Pendidikan Islam}

Vol. 2 No. 1 Juni 2020

organized.

\section{B. METODE PENELITIAN}

This research was an experimental study. This research was carried out at SDIT SABAR Prambanan in the academic year of 2012/2013. The population was the second grade students of SDIT SABAR Prambanan in the academic year of 2012/2013. The samples were two classes. The researcher took II.A as experimental class and II.B as control class. In determining the sample, the reseracher tok the samples of this study by using cluster random sampling. Each class was divided into two groups (the students having high and low creativity). The research instruments consist of students' creativity test and a vocablary test. The creativity test was readable and vocabulary test was valid and reliable after they were tried out. The data were the result of vocabulary test and analyzed by multifactor analysis of variance $2 \times 2$ (ANOVA). Then, it was analyzed by using Tukey.

\section{HASIL DAN PEMBAHASAN}

To teach vocabulary, the teachers have to select the suitable technique that is supposed to maintain and motivate the students in joining the class. According to Cameron states that vocabulary memorizing activities can make central use of the idea of networks of meaning. Based on that theory, one of the techniques to teach vocabulary is by memorizing because vocabulary is generally a matter of remembering. Thornbury proves that to be able to teach vocabulary, it is important to know how words are remembered and stored in students' minds and how long term memory is organized.

One of the techniques that can be used in memorizing the words is mnemonic. Mnemonic is tricks to help retrieve items or rules that are stored in memory and that are not yet automatically retrievable4. Mnemonic enhances meaningfulness of information and it is helpful for students to practice using word orally or in written text. On the other hand, mnemonic connects words, which is used as a spelling aid. This technique is helpful because words are more easily memorized when alliteration and rhyme reinforce them. The activities which are practiced in mnemonic are: (1) The teacher uses music (song) to pronounce the words; (2) The teacher asks the students to remember the keyword by linking information to familiar material (sounds and meanings are both given consideration), envision the picture and how it relates to the definition, and finally recall the definition; (3) Create the first or more than one letter of each word in a list of items to make a name of a person or thing. In this case, this activity will help the students to spell the words easily; and (4) Arrange guided practice with relevant feedback on both strategy usage and attribution feedback5. The indicators of vocabulary covering meaning, spelling, pronounciation, and use are developed through an activity in Mnemonic Technique. Indicator of meaning is develop when learners make a key word, imagine the word by using the picture, produce the words, and finally recall the words together. Spelling is developed when the learners create the words to find it easier to spell the words. Pronounciation is developed when the learners sing the words through the song. Use is developed when all students practice the words

\footnotetext{
${ }^{4}$ Ur, Penny. 1996. A Course in Language Teaching. United Kingdom: Cambridge University Press page 34

${ }^{5}$ Congos, Dennis. (2005). 9 Types of Mnemonics for Better Memory. Retrieved from

http://www.learningassistance.com/2006/january/mnemonics.html
} 
together.

Besides the techniques used by the teachers, another factor that plays an important role in teaching learning process is students' creativity. Creativity is known as a general ability to create something new and to share new ideas implemented in problem solving6. In learning process, creativity could not be obeyed in order to fulfill the target of leaning. Students having high creativity usually perform better learning than students having low creativity. They will memorize vocabulary better by mnemonic technique taught by teacher. The teacher's explanation will be practiced it, even they try a new way innovation in learning that is better than previous one. Moreover, students having high level of creativity will be faster and easier to express their good ideas in learning process7.

Finally, the objectives of the study are to find out whether: (1) Mnemonic is more effective than direct instruction to teach vocabulary; (2) The students having high creativity have better vocabulary mastery than those having low creativity; (3) Whether there is an interaction between teaching techniques and creativity in teaching vocabulary. Considering of the background that have been explained above, the researcher states that the problemsn to be researched as follows:

Is Mnomenic more effective than direct instruction to teach vocabulary?

Do students who have high creativity have better vocabulary mastery than those who have low creativity?

Is there any interaction effect between teaching techniques and students' creativity on the students' vocabulary mastery?

In accordance with the problems above, this research is intended:

To know weather mnomenic is more effective than direct instruction to teach vocabulary.

To know weather the students who have high creativity have better vocabulary mastery than those who have low creativity.

To know weather there is interaction effect between teaching techniques and students' creativity on the students' vocabulary mastery.

There are some definitions of vocabulary according to some experts. According to Caroline and David8, vocabulary is the collection of words that an individual knows. Hatch and Brown9 prove that the term of vocabulary refers to a list or set of words for a particular language or words that individual speakers of language might use. Ur argues that vocabulary is the words we teach in the foreign language. It means that all words in foreign language that have been taught by teachers in order that the students can use those words in sentences or daily communication.

Crystal states that the vocabulary of a person is defined either as the set of all words that are understood by that person or the set of all words likely to be used by that person when constructing new sentences. Brown views vocabulary items as a

\footnotetext{
6 Munandar, Utami S C. 1988. Kreativita Sepanjang Masa. Pustaka Sinar Harapan: Jakarta page 23

${ }^{7}$ Thompson. I. (1987). Memory in language learning. In A. Wenden 8J. Rubin (Eds). Learner Strategies in

Language Learning. (pp. 15-30). Newjersy: Prentic-Hall

${ }^{8}$ Chruickshank, Donald R, Bainer, Deborah I, and Metcalf, Kim K. 1997. The Act of Teaching. Macgraw-hill College page 121

${ }^{9}$ Brown, H Douglas. 2001. Teaching by Principles An Interactive Approach to Language Pedagogy. San Francisco State University: Longman page 1
} 


\section{At-Turats: Jurnal Pendidikan Islam}

Vol. 2 No. 1 Juni 2020

boring list of words that must be defined and memorized by the student, lexical forms are seen in their central role in contextualized, meaningful language.

Cerce and Murcia state that vocabulary is central to language acquisition whether the language is first, second or foreign language. It is real that vocabulary plays an important role for everyone who wants to learn and master the language skills.

Nation states that the learner needs to know of the "words". It means that students need to know the words not only the meaning but also the spelling, pronouncing, and the usage of words.

Based on the explanations above, it can be concluded that vocabulary is a set of words or collection of words that must be defined and memorized by a student or individual speaker in order to construct new sentences or words covering of its meaning, pronunciation, spelling, and use.

Mnemonics rely on associations between easy-to-remember constructs which can be related back to the data that are to be remembered. This is based on the observation that the human mind much more easily remembers spatial, personal, surprising, physical, sexual or humorous or otherwise meaningful information, as compared to retrieving arbitrary sequences. Mnemonic according to Congos is memory devices that help learners recall larger pieces of information.

Mnemonic is tricks to help retrieve items or rules that are stored in memory and that are not yet automatically retrievable. For vocabulary learning, they are used to relate the word to some previously learnt information, using some forms of imagery or grouping (Mastropieri and Scruggs, 1991). Thompson in Amiryousefi \& Ketabi similarly acknowledge the usefulness of mnemonic by stating that they can help learners learn faster and recall better by integration of new material into existing cognitive units and by providing retrieval cues. Cameron (2001: 87) adds that vocabulary memorizing activities can make central use of the idea of networks meaning.

Based on the research done by several researchers, after the students learn words by using mnemonic, they will enhance meaningfulness of information easily. Automatically, if the students have known the meaning of the words, they will not find difficult the usage of words. It was found that using mnemonic is a wonderful and fun way to help students put information into their long-term memory. Mnemonic tries to give some of the students some help to remember how to spell words. Not only does it help them spell the words, it also found that using a mnemonic is very effective in pronouncing the words. Pronouncing the word enables the students to remember it longer and identify it more readily.

From the definitions above, it can be concluded that mnemonic is memory devices that help learners recall larger pieces of information that serve the information during the storage process in order to improve ability of retrieving items or something. As a result, mnemonic helps the students learn faster and recall words better by providing retrieval cues and relating the words to some previously learn information. Moreover, mnemonic help students how to spell, pronounce, and use the words effectively.

From the theories from some experts, it can be assumed that there are several procedures used in teaching vocabulary by using mnemonic:

Step 1. The teacher Informs students about the purpose of the instruction and the 
rationale for the technique training and ordering information to be learned

Step 2. The teacher uses music (song) to pronounce the words. Music can be used to help students recall important details to main. Automatically, they also will remember better the way to pronounce the words.

Step 3. The teacher will ask the students to remember the keyword by linking information to familiar material (sounds and meanings are both given consideration), envision the picture and how it relates to the definition, and finally recall the definition. When asked to recall the definition of words, students engage in a four-step process: (a) think back to the keyword (b) think of the picture (c) remember what else was happening in the picture; and (d) Produce the definition.

Step 4. Create the first or more than one letter of each word in a list of items to make a name of a person or thing. In this case, this activity will help the students how to spell the words easily.

Step 5. Arrange guided practice with relevant feedback on both strategy usage and attribution feedback. Provide corrective feedback and allow opportunities for students to share their thinking with one another about how they developed their strategies. In this activity, the students do not only practice the words which have been learned but they also practice in real context orally or in written form using the simple sentence.

Creativity is one of the aspects that should be taken into consideration. Creativity is one's ability to bear something new in the form of ideas or real work having creative or affective thought. Creativity is defined as the tendency to generate or recognize ideas, alternatives, or possibilities that may be useful in solving problems, communicating with others, and entertaining ourselves and other10. Supriadi states that creativity is someone's ability to create something new which is different from the previous one. Creativity is an important human characteristic. It is perhaps best thought of as a process, requiring a mixture of ingredients, including personality traits, abilities, and skills.

In contrast, Direct Instruction characterized by teacher-centered and teacherdominated classroom. In this technique, the teacher becomes the decision maker. The teacher's control occurs when the teacher selects and directs the learning tasks. Direct Instruction was specifically designed to promote student learning of procedural knowledge and declarative knowledge that can be taught in step-by-step fashion. Direct instruction is usually deductive. That is, the rule or generalization is presented and then illustrated with examples. While this strategy may be considered among the easier to plan and to use, it is clear that effective direct instruction is often more complex than it would first appear.

According to Joyce and Weil the teacher also provides feedback and correction for the students' mistake. Direct instructional model is one of the highest priorities on the assignment and complexion of academic tasks in the classroom. Direct Instruction is one of which there is a predominant focus on learning and in which students are engaged in academic tasks, a large percentage of time and achieve at a high rate of

10 OSHO. (2012). What is Creativity. Retrieved from http://www.osho.com/en/highlights-of-oshos-world/what-iscreativity/ 


\section{At-Turats: Jurnal Pendidikan Islam}

Vol. 2 No. 1 Juni 2020

success11. Direct instructional is similar to traditional teaching. Generally vocabulary traditional teaching is directed toward teaching academic content.

According to Hansen and Eller direct instruction includes frequent lesson where the teacher presents information and develop concept through demonstration and lectures, most of the lectures involve questioning students and providing feedback. When students respond the teachers' questions, the teachers provide appropriate feedback.

Based on explanation above, direct instruction is teacher-centered technique that includes frequent lesson where the teacher presents information and develop concept through demonstration and lectures which are focused on utilizing systematic and explicit instruction by providing feedback and correction of students' mistake to engage them in successful academic task. Moreover, direct instruction is specifically designed to promote student learning of procedural knowledge and declarative knowledge.

From the theories from some experts, it can be summarized that the procedures of direct instructions are as follows:

Step 1: Teacher goes over objective for the lesson, gives background information, and explains why the lesson is important. Get students ready to learn.

Step 2: Teacher explains a new word, going beyond reciting its definition. Students restate or explain the new word in their own words (verbally and writing). In this activity, the students can see and learn not only the meaning but also the spelling of the words that is being presented by the teacher.

Step 3. Teacher has students speak based the words which have been explained. Teacher pronounces each word for students and has the students repeat after the teacher.

Step 4. Teacher sets conditions for extended practice with attention to transfer to more complex and real life situations. In this activity, the students are asked to practice written or orally of words that the teacher has explained in real context.

Step 5. Determining whether students have mastered content materials. This is done with the students "practicing" in a group. Teacher provides students practice in their learning, asks questions, and gives students an opportunity to presents what they have learned in front of their group.

Step 6. Giving feedback and corrective information to students on their answers to questions and on their written assignment.

Creativity refers to the phenomenon whereby a person creates something new (a product, a solution, a work of art, a novel, a joke, etc) that has some kind of value. What counts as "new" may be in reference to the individual creator, or to the society or domain within which the novelty occurs.

According to "Heritage Illustrated Dictionary"12 there are three aspects of

11 Bruice joyce . mashal weil. emily calhoun : model of teaching page 338.

\footnotetext{
${ }^{12}$ Heritage Illustrated Dictionary. (1999, August 14) retrieved from http://members.optusnet.com.au/charles57/Creative/Basics/definitions.htm
} 
creativity. They are as follows:

a. The creative process which focuses on the mechanisms and phases involved as one partakes in a creative act.

b. The creative person aspect which has central focus on personality traits of creative people.

c. The criteria or characteristics of creative products which become performance assessment of real world creativity.

Gordon in Joyce, et al., (2000: 221-222) grounds synectics in four ideas about creativity: (1) creativity is important that in daily activities. He adds that creativity as a part of our daily work and leisure live; (2) the creative process is not at all mysterious. It can be described, and it is possible to train persons directly to increase their creativity; (3) creative invention is similar in all fields_the arts, the sciences -and is characterized by the same underlying intellectual processes; and (4) individual and group inventions (creative thinking) are very similar.

It can be concluded that creativity is a person's ability to create something new as he tendency to generate or recognize ideas, alternatives, or possibilities that may be useful in solving problems, communicating with others, and entertaining ourselves and others. Creativity has three aspects, namely: (1) creative process; (2) creative person; and (3) characteristics of creative product that creativity it self has been as a part of our daily work and leisure live. Creativity viewed as aptitude traits is a divergent thinking ability which involves some mental characteristics of fluency of thinking, flexibility of thinking, originality, and elaboration.

Based on the theoretical description and rationale above, the hyphotheses can be formulated as follows:

Mnomenic is more effective than direct instruction to teach vocabulary in second grade students of SDIT Salsabilla Baiturrahman Prambanan.

The students having high creativity have better vocabulary mastery than those having low creativity.

There is an interaction between teaching techniques and students' creativity on the vocabulary mastery of the students in second grade students of SDIT Salsabilla Baiturrahman Prambanan

\section{Research Methodology}

The study was an experimental design, since it described the quantitative degree to which variables are related. It is also reasonable that the writer intends to examine the cause and effect among the variables, those are Mnemonic and Direct Instruction in teaching vocabulary from students' creativity. The research design used in this research was simple factorial design. The study tried to describe the effect of treatment of Mnemonic and Direct Instruction in teaching vocabulary viewed from students' creativity.

This research design has several characteristics: (1) it has two groups of experimental subjects or experimental group and control group; (2) the two groups are compared with respect two measurements or observation on the dependent variable; (3) both group are measured using post-test; (4) measurement on the dependent variable 


\section{At-Turats: Jurnal Pendidikan Islam}

Vol. 2 No. 1 Juni 2020

for both groups will be done at the same time with the same test; and (5) the experimental group is manipulated with particular treatment.

The technique used in this research was descriptive and inferential analysis. The descriptive statistics was used to know the mean, median, mode, and standard deviation of students score for each group. Inferential statistics was used to test the hypothesis. In this study, the researcher also applied multifactor analysis of variance (ANOVA) that requires normality test to know whether the data from population is distributed normally and homogeneity to know whether the groups that are compared are homogenous. To be clearer, it is designed as follows:

Table B.1 Research Design

\begin{tabular}{|c|lc|lc|}
\hline $\begin{array}{c}\text { Teaching } \\
\text { technique } \\
\text { Creativity }\end{array}$ & $\begin{array}{r}\text { Mn } \\
\text { emonic } \\
\text { (A1 }\end{array}$ & \multicolumn{2}{|l|}{$\begin{array}{l}\text { ect } \\
\text { Instruction } \\
\text { (A2 }\end{array}$} \\
\hline $\begin{array}{c}\text { High } \\
\text { Creativity(B1) }\end{array}$ & B1 & A1 & B1 & A2 \\
\hline $\begin{array}{c}\text { Low } \\
\text { Creativity(B2) }\end{array}$ & B2 & A1 & B2 & A2 \\
\hline
\end{tabular}

Result and Discussion

Table 1. Summary of a 2x2 Multifactor Variance

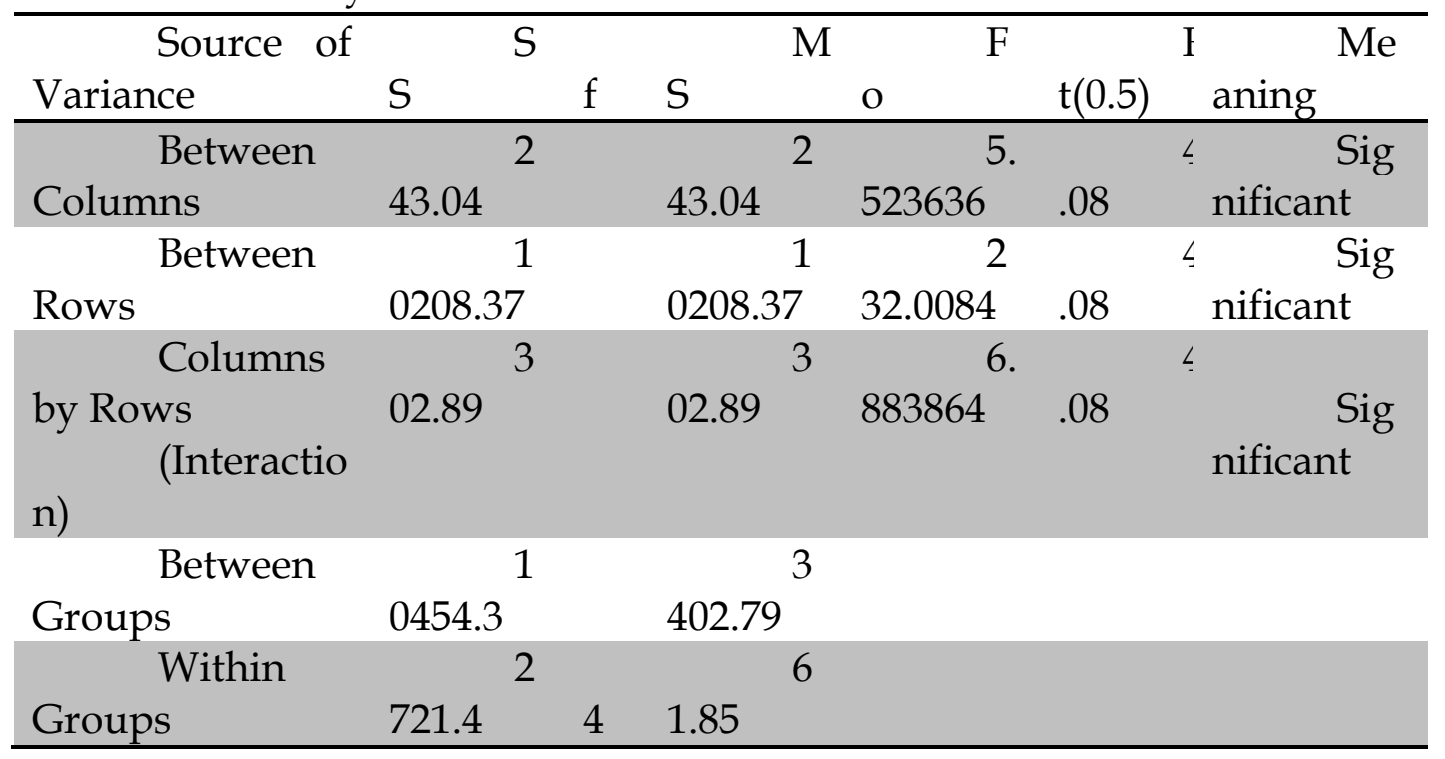

Based on the above table, it can be concluded that:

Because Fo between columns (5.523636) is higher than Ft at the level of significance $a=0.05$ (4.26), so the difference between columns is significant. It means that the null hypothesis (H0) which states that there is no significant difference in teaching vocabulary mastery between using Mnemonic and using Direct Instruction is rejected. Because the mean of A1 (72.64) is higher than that of A2 (68.17), it can be concluded that mnemonic is more effective than Direct Instruction to teach vocabulary.

Because Fo between rows (232.0084) is higher than Ft at the level of significance 
$a=0.05$ (4.26), so the difference between rows is significant. It means that the null hypothesis (H0) which states that there is no significant difference in vocabulary mastery between the students who have high level of creativity and students who have low level of creativity is rejected. Then, because the mean of B1 (85) is higher than B2 (55.83), it can be concluded that the students having high creativity have better vocabulary mastery than those having low creativity.

Because Fo columns by rows (6.883864) is higher than Ft at the level of significance $a=0.05$ (4.08), Ho is rejected and there is an interaction between learning techniques and students' creativity. Thus, it can be concluded that the effectiveness of learning techniques to teach vocabulary depends on the level of students'creativity.

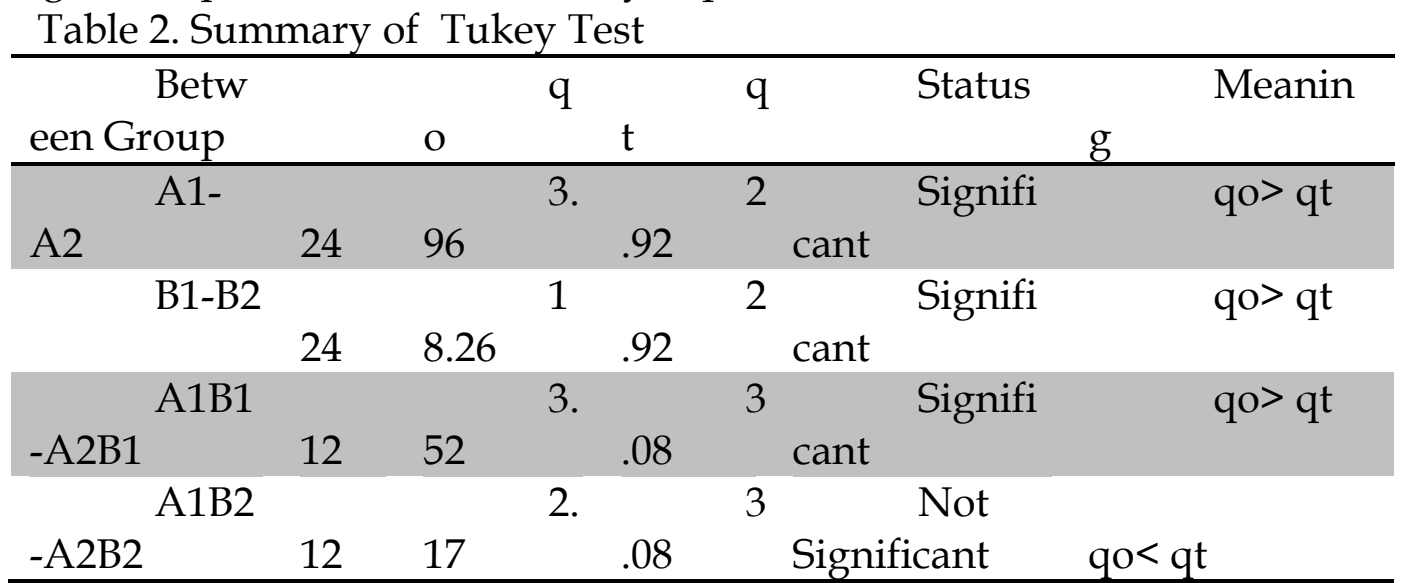

Based on the summary of Tukey test, it can be concluded that:

qo between columns (3.96) is higher than qt (2.92), so the difference between columns is significant. It can be concluded that teaching vocabulary using Mnemonic to the second grade students at SDIT Salsabilla Baiturrahman Prambanan is significantly different from the one using Direct Instruction. The mean score of students taught using Mnemonic (72.6667) is higher than the one of those taught using Direct Instruction (68.17). It means that teaching vocabulary using Mnemonic to the second grade students at SDIT Salsabilla Baiturrahman Prambanan is more effective than the one using Direct Instruction..

qo between rows (18.26) is higher than qt (2.92), so the difference between rows is significant. It can be concluded that the students who have high creativity are significantly different in vocabulary mastery from the students who have low creativity. The mean score of students having high creativity (85) is higher than the one of those who having low creativity (55.83), so the students who have high creativity have a better vocabulary mastery than the students who have low creativity.

qo between columns for students with high creativity (3.52) is higher than qt (3.08), so the difference between columns for students with high creativity is significant. It can be concluded that teaching vocabulary using Mnemonic to the second grade students having high creativity is significantly different from the one using Direct Instruction. The mean score of students having high creativity taught using Mnemonic (87) is higher than the one of those taught using Direct Instruction (83). It means that teaching vocabulary using Mnemonic to the second grade students having high creativity is more effective than the one using Direct Instruction.

Because qo between column by cell (A2B2-A1B2) (2.17) is lower than qt at the level of significance $a=0.05$ (3.08), the difference between columns for students having 


\section{At-Turats: Jurnal Pendidikan Islam}

Vol. 2 No. 1 Juni 2020

low creativity is not significant. It can be concluded that teaching vocabulary using mnemonic to the second grade students having low creativity is not significantly different from the one using direct innstruction. It means that students with low creativity will almost have the same result when they are taught using both techniques, Mnemonic and Direct Instruction.

\section{Discussion}

This research is one of the efforts to generate some improvement in teaching vocabulary to the second grade students of elementary school students. It has been discussed in the previous chapter that Mnemonic is one of the techniques to obtain the intention. The following is the elaboration discussions of the research findings.

Mnemonic is more effective than Direct Instruction

Mnemonic is an effectiveness way of enhancing vocabulary learning and recall. It also helps learners elaborate the words. In mnemonic, the students do not feel hard to spell the word, acquire the word, understand the meaning, and use it in a sentence. Mnemonics are used to improve retention of memory. Mnemonic can relate new information to information that students already have stored in their long-term memory. Mnemonic provides retrieval clues that make the student recall better the words which have been explained. This condition will always create a positive atmosphere of learning the words covering of four indicators of vocabulary (its meaning, spelling, pronouncing, and using the words). The activities which are practiced in mnemonic are begun from music (song) mnemonic to pronounce the words then the students to remember the keyword by linking information to familiar material (sounds and meanings are both given consideration), envision the picture and how it relates to the definition, and finally recall the definition. Finally, the learners have to create the first or more than one letter of each word in a list of items to make a name of a person or thing. Thompson in Amiryousefi \& Ketabi 13says that mnemonic helps learners learn faster and recall better by integration of new material into existing cognitive units and by providing retrieval cues. Cameron adds that vocabulary memorizing (mnemonic) activities can make central use of the idea of networks meaning. So, Learning vocabulary by mnemonic arouses students' attention in learning because of colourful activities provided in learning process.

Meanwhile, direct instruction is a teacher-centered approach. The direct instruction is highly teacher-directed. Tecaher always . Cruichkshank, et al. states that direct instruction refers to a pattern of teaching which consist of teacher's explaining a new concept to a large group of the students where the way of the explanation is straightforward way where the teacher always gives feedback and correction for the mistake that students' made. Teachers cannot assess the students' prior knowledge, so they will be unaware of why particular students cannot learn. Moreover, the students do not have chance to develop their creative thinking in learning because the teacher as a whole decision maker in learning process.

Therefore, it can be concluded that Mnemonic is more effective than Direct Instruction to teach vocabulary.

The Students Having High Creativity have Better Vocabulary Mastery than those

\footnotetext{
${ }^{13}$ Thompson. I. (1987). Memory in language learning. In A. Wenden 8J. Rubin (Eds). Learner Strategies in Language Learning. (pp. 15-30). Newjersy: Prentic-Hall 139
} 


\section{Having Low Creativity}

Creativity is one of factors infleuncing students to reach the success of learning. Creativity refers to the phenomenon whereby a person creates something new such as: a product, a solution, a work of art, a novel, a joke that has some kind of value. Moreover, someone is able to create a new innovation, find the best solution of the problems, get along to others, it is because of his/her creativity. Supriadi in (Sri Narwanti, 2011: 4) states that creativity is someone's ability to create something new which is different from the previous one.

The students are categorized having high creativity when they are able to think creatively. Students came up with high creative ideas seems to have eliminated any problems in learning. They have a big willigness to create a new innovation in their learning. They are able to produce the newly learned words that their teacher has given. In this case, students having high creativity tend to produce and recall the words more in excellent ways that are different with others. High creativity has certain characteristics such as innovation/novelty, excellence, recognition by the field within which it takes place and a break with past understandings14. Thus, students having high level of creativity will be faster and easier to express their good ideas in learning process.

In contrast, the students having low creativity tend to be passive in the class. They are lazy, spiritless, and shy to do something because there is no purpose in joining the class. The students having low creativity look silent without doing anything during the vocabulary class. Consequently, the teacher should treat and control them intensively to enhance their creativity in learning vocabulary. OSHO sates that uncreative refers to an unable person to produce new ideas, new action, while innovation is the process of both generating and applying such creative ideas in some specific context15. The students who have low creativity will have difficulty in understanding what their teacher has explained. They do not have big willingness to create and produce the newly learned word, even try to find new innovation in learning vacabulary.

In line with the explanations about, the students having high creativity have better vocabulary mastery than those having low creativity.

There is an Interaction between Learning technique and Students' Creativity

In reaching the students' vocabulary mastery as good as possible, the teachers have to select the suitable technique that is supposed to maintain and motivate the students in joining the classroom learning. In Mnemonic technique, the teacher tries to create new way of learning that the teacher never applies before in teaching vocabulary. Mnemonic activities are begun from music that is used to pronounce the words, the teacher asks the students to remember the keyword by linking information to familiar material (sounds and meanings are both given consideration), envision the picture and how it relates to the definition, and finally recall the definition, create the first or more than one letter of each word in a list of items to make a name of a person or thing. In this case, this activity will help the students to spell the words easily. In this technique,

\footnotetext{
${ }^{14}$ Gardner, Howard. (2001). Creativity in Education. New York: Continuum page 46

15 OSHO. (2012). What is Creativity. Retrieved from http://www.osho.com/en/highlights-of-oshos-world/what-iscreativity/
} 


\section{At-Turats: Jurnal Pendidikan Islam}

Vol. 2 No. 1 Juni 2020

students encode information in a more meaningful form and to provide them with a retrieval route at the time of recall. Thornbury (2002: 25) states that Mnemonic helps retrieve items or rules that are stored in memory.

In applying Mnemonic, the students should have high creativity because they have to explore their thinking innovatively to produce the new words. Having high creativity is needed when the learners apply an innovation way in learning to create the key words to recall the meaning of words individually or in group. In remembering the keyword, the students link information to familiar material, including sounds and meanings. Having high creativity students are able to envisage the picture and relate it to the definition, so it will help the students recall a new word. Creativity is a state of mind in which all of our intelligences are working together. It involves seeing, thinking, and innovating16. In this case, the creativy students is one of factors supporting the students to get success in learning vocabulary. Thus, mnemonic is more effective than direct instruction to teach vocabulary for the students who have high creativity.

Based on the result of this research, the effectiveness of both mnemnic and Direct Instruction are similar for teaching vocabulary for students having low creativity. It means that neither of the learning technique is more effective than the other or Mnemonic is as effective as Direct Instruction to teach vocabulary for students having low creativity. The effectiveness of both Mnemonic and Direct Instruction are similar for teaching vocabulary for students having low creativity because whatever learning techniques are used, they do not give any effect to the students having low creativity. Students having low creativity tend to be passive in doing the task. They do not have any willingness to do something. According to Fasko (2001: 3) a learning technique is not successfully applied when it is taught to the low creativity student. It can be concluded that students having low creativity have almost similar vocabulary mastery whether they are taught using Mnemonic or Direct Instruction.

\section{KESIMPULAN}

(1 spasi)

It has been clearly described on the previous chapter that the research findings are as follows: (1) Mnemonic is more effective than direct instruction to teach vocabulary; (2) The students having high creativity have better vocabulary mastery than those having low creativity; (3) there is an interaction between teaching techniques and creativity in teaching vocabulary.

Based on the research findings, the conclusion is that the Mnemonic is more effective than direct instruction to teach vocabulary. The activities which are applied in mnemonic are begun from music (song) to pronounce the words then the students to remember the keyword by linking information to familiar material (sounds and meanings are both given consideration), envision the picture and how it relates to the definition, and finally recall the definition. Finally, the learners have to create the first or more than one letter of each word in a list of items to make a name of a person or thing. The result of the study also shows that high creativity students have a better result of vocabulary than low creativity students. It is not only for getting good scores but also

${ }^{16}$ Craft et. al. (2001). Creativity in Education. London: Continuum 38 
for achieving good vocabulary mastery that is useful for their future. It means that Mnemonic is more suitable for high creativity students in improving the students' vocabulary mastery.

Based on the conclusions and implications written earlier, there are some suggestions. The teaching technique which is used by the teacher in the class gives a big influence for the success of the teaching and learning process. To teach vocabulary, the teachers have to select the suitable technique that is supposed to maintain and motivate the students in joining the class. Mnemonic provides retrieval clues that make the student recall better the words have been explained. This condition will always create a positive atmosphere the students' memorization of the words covering of four indicators of vocabulary (its meaning, spelling, pronouncing, and use the words). That's why, it is recommended for teacher to apply it in their class.

\section{REFERENSI}

Amiryousefi, M \& Ketabi, S. (2011). Mnemonic Instruction: A Way to Boost Vocabulary Learning and Recall. Journal of Language Teaching and Research, Vol. 2, No. 1, pp. 178-182. doi:10.4304/jltr.2.1. Retrieved from Academy Publisher Manufactured In Finland.

Arends, Richard I. 1997. Classroom Instruction and Management: United stated. McGraw-Hill.

Brown, H Douglas. 2001. Teaching by Principles An Interactive Approach to Language Pedagogy. San Francisco State University: Longman.

Bruice joyce . mashal weil. emily calhoun : model of teaching.

Celce-Murcia, M. (2001). Teaching English as a Second or Foreign Language. USA: Heinle and Heinle.

Chruickshank, Donald R, Bainer, Deborah I, and Metcalf, Kim K. 1997. The Act of Teaching. Macgraw-hill College.

Congos, Dennis. (2005). 9 Types of Mnemonics for Better Memory. Retrieved from http://www.learningassistance.com/2006/january/mnemonics.html.

Craft et. al. (2001). Creativity in Education. London: Continuum

Crystal, D. 2003. Cambridge Encyclopedia of the English Language. CambridgeUniversity Press. ISBN 0521596556.

Fasko, Daniel (2001) Creativity Research Journal: Creativity and Education. Vol 13. Lawrence Erlbaum Associates, Inc

Folse, K. (2004). Intermediate Reading Practices: Building Reading and Vocabulary Skills, 3rd Edition. Ann Arbor: University of Michigan Press.

Fulk, B.J. M., Mastropieri, M. A., \& Scruggs, T. E. (1992). Mnemonic generalization training with learning disabled students. Learning Disabilities Research and Practice, 7, 2-10.

Gall, M. D., P. Gall, J., \& R. Borg, W. (2003). Educational Research: An Introduction. the United States: Allyn \& Bacon.

Gardner, Howard. (2001). Creativity in Education. New York: Continuum.

Hanson, Kenneth T \& Eller, Ben F. 1998. Educational Psychology for Effective Teaching. United States. Wardsworth Publising Company.

Heritage Illustrated Dictionary. (1999, August 14) retrieved from http://members.optusnet.com.au/charles57/Creative/Basics/definitions.htm

Hughes, Arthur. (1989). Testing for Language Teaching. Cambridge: Cambridge University Press.

Joyce, Bruce and Marsha Well. 1986. Models of Teaching. New Jersey: PrenticeHall, Inc.Language Learning, 6, p.23-41.

Malaguzzi (2009, May 18/19). Creativity Inovation and Impelemntation [Power Point Slide]. Retrieved from http://www.creative-partnerships.com.

Mayer, Richard E. (2003). Learning and Instruction. Upper Saddle River, New Jersey: Merrill Prentice Hall. Oxford English Dictionary. 2002. 


\section{At-Turats: Jurnal Pendidikan Islam}

Vol. 2 No. 1 Juni 2020

Munandar, Utami S C. 1988. Kreativita Sepanjang Masa. Pustaka Sinar Harapan:

Jakarta.

Munandar, Utami S C. 1999. Pengembangan Kreativitas Anak Berbakat. Rineka Cipta : Jakarta.

Nation, I.S.P. 2008. Teaching and Learning Vocabulary. Boston: Massachusets.

Nation, Paul. 2005. "Teaching Vocabulary” Asian EFL Journal, Vol 7, Issue 3, Article 4, September 2005.

Nunan, David. 1989. Designing Tasks for Communicative Classroom. Cambridge:

Cambridge University Press.

OSHO. (2012). What is Creativity. Retrieved from http://www.osho.com/en/highlights-of-oshosworld/what-is-creativity/

Paivio, A. (1971). Imagery and Verbal Processes. New York: Holt, Rinehart, and Winston.

Scruggs, T. and M. Mastropieri. (1992). Classroom Application of Mnemoniclnstruction: Acquisition, Maintenance, and Generalization. Exceptional Children, 58: 219-229.

Solso, R. L. (1995). Cognitive Psychology (4th Ed.). Boston: Allyn and Bacon.

Sri Narwanti. (2011). Creative Learning: Kiat Menjadi Guru Kreatif dan Favorit. Yogyakarta: Familia Pustaka Keluarga.

Thompson. I. (1987). Memory in language learning. In A. Wenden 8J. Rubin (Eds). Learner Strategies in Language Learning. (pp. 15-30). Newjersy: Prentic-Hall.

Thorbury, Scott. 2002. How to Teach Vocabulary. England: Longman 